\title{
202 I Pierre Lalive and John Henry Merryman Fellowship in art and cultural heritage law
}

\author{
Awarded to Tamás Szabados, "In Search of the Holy Grail of the Conflict of \\ Laws of Cultural Property"
}

The International Cultural Property Society and the Art-Law Centre of the University of Geneva has established an annual fellowship, in honour of Professors Pierre Lalive and John Henry Merryman, aimed at the promotion and development of emerging scholars in the field of international cultural heritage law and related fields such as art law and museum law.

Pierre Lalive (1923-2014) was a Professor of law at the University of Geneva and founding partner of LALIVE in Geneva. He was a leading art law scholar particularly in private international law and was instrumental in the drafting of the 1995 UNDROIT Convention on the Stolen or Illegally Exported Cultural Objects.

John Henry Merryman (1920-2015), the Nelson Bowman Sweitzer and Marie B. Sweitzer Professor of Law, Emeritus at Stanford Law School was a leading art law scholar particularly in comparative law. He founded the International Cultural Property Society in 1988, which publishes the International Journal of Cultural Property (Cambridge University Press), and was co-author of Law, Ethics and the Visual Arts (with Albert E Elsen).

The Fellowship is awarded to a scholar for the best article published in the International Journal of Cultural Property in the preceding calendar year. To be eligible, the author must have been under 40 years of age at the time of the article's submission.

The Pierre Lalive \& John Henry Merryman Fellow in art and cultural heritage law is a residency fellowship hosted by the Art-Law Centre of the University of Geneva for a period of no less than two, and no more than four, weeks, at a time mutually convenient to the Centre and the Fellow during a twelve (12) month period running from 1 June in the year of the award's announcement. During the visit, the Fellow is expected to work on publishable research and engage in the activities of the Centre. The Fellow will be provided with office and library facilities.

Past awardees:

2019 Tabitha I. Oost

2020 Luke Tattersall

Cite this article: "2021 Pierre Lalive and John Henry Merryman Fellowship in art and cultural heritage law." International Journal of Cultural Property 28, no. 1: 1. https://doi.org/10.1017/S0940739121000254 